\title{
Effect of Storage Conditions on Quality of Ready-to-Serve Beverage from Residual Osmotic Solution of Star Fruit
}

\author{
Behera Gitanajli* ${ }^{1 *}$ Panigrahi $\mathrm{SS}^{2}$, Rayaguru $\mathrm{K}^{3}$ \\ 1,2Department of Food Process Engineering, National Institute of Technology, Rourkela, India-769 008 \\ ${ }^{3}$ Department of Agricultural Processing and Food Engineering, CAET, OUAT, Bhubaneswar, India-753 001 \\ Email: gitanjalibehera001@gmail.com
}

\begin{abstract}
Increasing urbanization has boosted the demand for health related drinks based on indigenous fruits. Star fruit due to its high antioxidant potentials along with abundance in nutritional and medicinal qualities has been recently scrutinized for producing commercialized value added products. Present investigation is undertaken with a view to augment the use of resulting osmotic solution with fresh carambola juice for preparation of ready to serve beverage and to determine their storability with respect to quality characteristics. The formulated ready-to-serve (RTS) beverage stored for six months under ambient $\left(25^{\circ}-43^{\circ} \mathrm{C}\right)$ and refrigerated $\left(10^{\circ} \mathrm{C}\right)$ condition exhibited overall sensory parameters within the limits of acceptance. With increasing storability, the ascorbic acid content decreased from a mean value of 23.94 to $18.42 \mathrm{mg} / 100 \mathrm{~mL}$ (ambient) and $21.86 \mathrm{mg} / 100 \mathrm{~mL}$ (refrigerated). Similarly, oxalic acid was reduced from $90.88 \mathrm{mg} / 100 \mathrm{~mL}$ to $63.85 \mathrm{mg} / 100 \mathrm{~mL}$ (ambient) and $88.55 \mathrm{mg} / 100 \mathrm{~mL}$ (refrigerated). After 4 months of storage the scores of the sensory properties of RTS were found to be reduced to below 7.5 for ambient and below 8.3 for refrigerated samples. The refrigerated stored sample showed higher retaining property for flavor attributes. Moreover, the stored samples manifested the presence of bacteria, mold and yeast, yet within the limit of acceptance.
\end{abstract}

Keywords: Star fruit, residual syrup, RTS beverage, antioxidant, sensory properties.

\section{Introduction}

Star fruit (Averrhoa carambola) is one of the tribal fruits grown in India. It is a multipurpose fruit which is gaining lot of priority for its therapeutic potentials. The fruit contains an edible pulp, exhibiting similar flavor properties as that of green sour apple. Moreover, it has been used for making commercialized products such as pickles, jams, jelly and beverages [1,2]. The fruit contains huge variety of bio-active components such as antioxidants, minerals, total phenolics, and dietary fibers. It is also a good source of potassium, copper, as well as folate and panthothenic acid [1]. High perishability during its harvesting has heavily restricted its utilization, producing wastes due to non-availability of adequate storage and processing [3]. Yet, the lack of technical knowledge for its further processing has rendered its potentials unutilized which makes it the most overlooked fruit for extracting essential therapeutic uses in the entire region [4]. Therefore, transportation, handling and, processing within a short span are major concerns in commercial scale processing [5]. There is a need to preserve their potentials through procuring acceptable techniques for safe storage with efficient nutrient retention [6].

In recent years, formulation of value added products has gathered essential priority for the use as a commercialized product $[7,8]$. Value added products manufactured during the harvesting seasons of a particular seasonal fruit are expected to be consumed throughout the year. With substantial promotions and research evidences, this underutilized fruit could play an important role as one of the alternative food sources to the world and in improving human health. Today, development of an elementary and economical process for star fruit preservation is highly solicited. A concern for osmo-dehydration in industries is the problem for the management of the resulting osmotic solution. Reuse by solute addition may lead to complete utilization of resulting syrup, thereby saving a major part of the investment in the osmo-dehydration process. Further, there is a growing demand for health drinks based on indigenous fruits [9]. Ready-to-serve (RTS) is a type of beverage containing at least $10 \%$ fruit juice besides less 
than $0.3 \%$ acid according to the FPO Standard [10]. It is normally not diluted before serving and hence known as RTS beverage.

To the best of our knowledge, no work has been done in the reuse of the residual osmotic star fruit syrup for the preparation of ready to serve the beverage. Hence the present work is undertaken with the objective for effective utilization of residual osmotic syrup which would otherwise be wasted and to determine its storability with respect to quality characteristics in terms of biochemical, microbial and sensory attributes.

\section{$2 \quad$ Materials and Methods}

\subsection{Sample Preparation and Pretreatment}

Star fruits "golden star variety" samples at proper maturity were procured from the Orissa University of Agriculture and Technology premises, Bhubaneswar during the month of January for relevant experimentations. The maturity stage was decided on the basis of their color and textural property [11]. The collected whole fresh fruits (Figure 1) were properly washed in the running water to remove dirt and foreign particles; surface moisture was wiped with a clean towel.

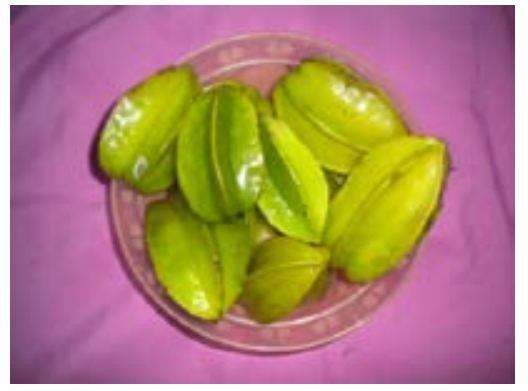

Figure 1. Whole star fruit

\subsubsection{Preparation of RTS from Fresh Starfruit}

The fruits were subjected to proper unit operations for extraction of fresh juice [12]. The cleaned star fruits were chopped into small pieces followed by the juice extraction by a screw type juice extractor. The extracted juice was strained through a double layer muslin cloth to obtain the clarified juice devoid of seeds and fiber particles. In a separate container, sugar syrup was prepared by mixing commercially available sugar so as to provide adequate textural property to the juice. Then RTS was prepared by mixing sugar syrup and fresh star fruit juice at required proportions (Figure 2). The final TSS (Total Soluble Solids) and juice percentage were maintained as per the FPO specification. For flavoring, the RTS was mixed with ginger juice at an amount of 15-16 mL per liter of RTS. Sterilized glass bottles of $200 \mathrm{~mL}$ capacity were filled with RTS and sealed by a crown cork sealing machine followed by resterilization for $20 \mathrm{~min}$. The mass flow chart for the RTS beverage prepared from the fresh sugar syrup is given in Figure 3.

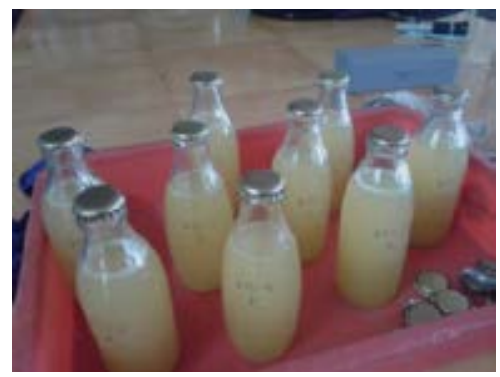

Figure 2. Prepared RTS beverage 


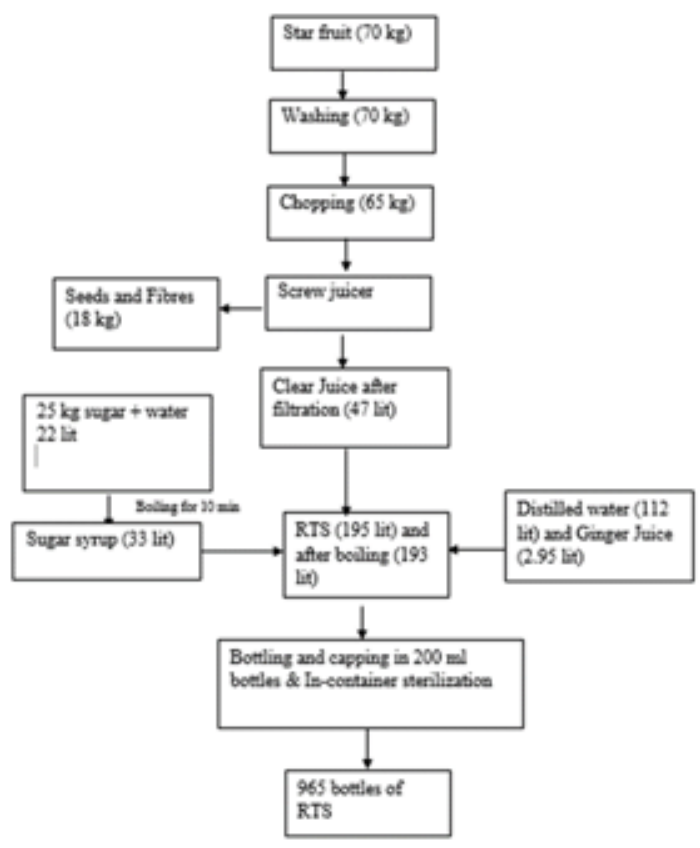

Figure 3. Mass flow chart for RTS beverage preparation from fresh sugar syrup

\subsubsection{Preparation of RTS Beverage Using Resulting Osmotic Solution}

For proper management of the left-over osmotic sugar solution, residual sugar syrup obtained from osmo-dehydration was mixed with distilled water and allowed to boil till leather foam formation was observed. The boiled syrup was filtered through 120 mesh sieve to remove the scum. Filtrate syrup was added to the fresh juice as per the requirement. A number of trials were made in order to meet the FPO specification and sensory acceptance. Adopting this method, some value-added beverage was prepared along with osmo-dehydrated slices. The flow chart of the osmo-dehydration along with RTS preparation is shown in Figure 4. The prepared RTS beverage was stored for six months under ambient $\left(25\right.$ to $\left.43^{\circ} \mathrm{C}\right)$ and refrigerated $\left(10^{\circ} \mathrm{C}\right)$ condition and the quality characteristics were evaluated. Since the experiment was continued for the month of January to June, the average temperature and $\mathrm{RH}$ ranged in this period was 25 to $43^{\circ} \mathrm{C}$ and 60 to $88 \%$, respectively.

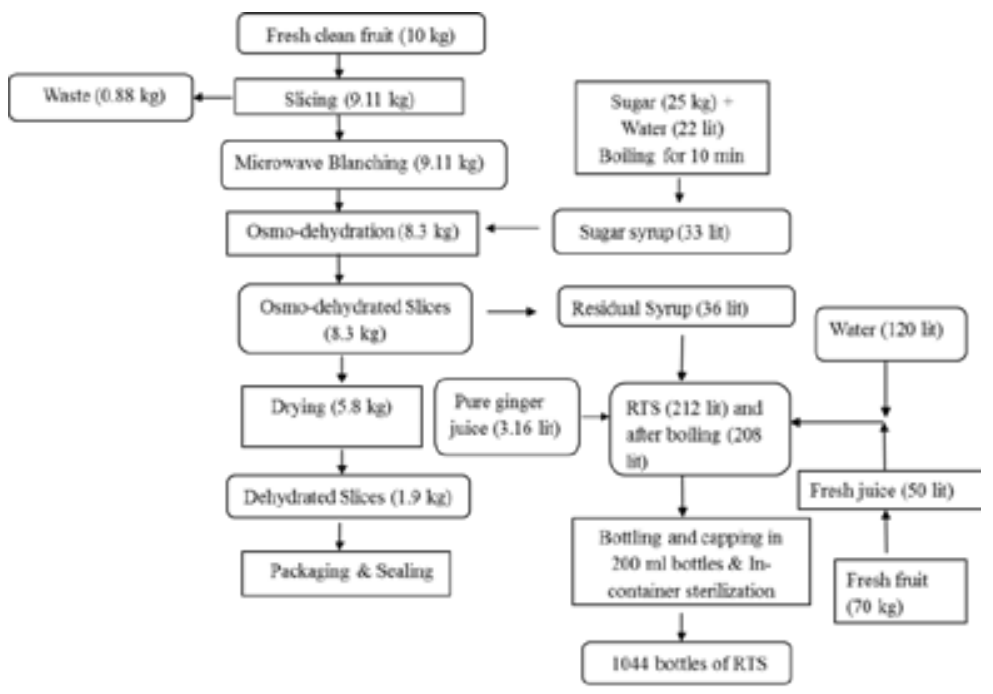

Figure 4. Mass flow chart for RTS beverage preparation from residual osmotic syrup 


\section{$2.2 \quad$ Organoleptic Quality Analysis}

Storage experiments were carried out for a period of six months and the quality analysis was made [5]. The periodical observations on biochemical qualities were evaluated by opening three bottles from each storage condition randomly. Both biochemical and microbial analysis were observed at every 60 days. The biochemical analysis included pH, TSS, total sugar, ascorbic acid and, oxalic acid. The $\mathrm{pH}$ was measured using a digital pH meter (model No L1 120, ELICO, INDIA). The TSS was determined using hand-held refractometer (Atago 2363 MASTER 500 ranging from 0.0-90.0\% Brix value) at $20^{\circ} \mathrm{C}$. Total reducing sugar was estimated by phenol-sulfuric acid method [13]. Ascorbic acid content (AA) was determined by using 2, 6-dichloroindophenol titrimetric method [14]. The oxalic acid (OA) content was evaluated by titration method [15]. In the microbial analysis, plate count method was used in which surface microbial load was calculated for bacteria in nutrient agar media while yeast and mold count was determined in potato dextrose media [16].

\subsection{Sensory Evaluation}

Sensory evaluation of the star fruit beverage was performed using nine-point hedonic scoring test. Ten trained panel members were considered for the purpose. Taking the weight factor for different organoleptic attributes like flavor, color, taste, overall acceptability was calculated using composite scoring. The scoring system considered was a 9-point scale system with the quality index like extremely (9) to dislike extremely (1). Eventually, weighting factor has been determined from priority percentage data collected from a semi-trained panel consisting of professors, technicians and students of the university. The arithmetic average factor for color, flavor and, the taste was determined to be 30, 40, and $30 \%$ respectively.

\subsection{Statistical Evaluation}

All biochemical and microbial qualities of the developed RTS were subjected to measures of central tendency, and the mean and standard deviation of biochemical qualities were determined. Analysis of variance (ANOVA) was performed for biochemical qualities using the Microsoft Excel (version 2013). All the determinations were carried out in triplicate.

\section{$3 \quad$ Results and Discussion}

\subsection{Quantification of Juice and RTS Beverage}

Results indicated that among the trials with different juice content, a beverage with juice content of $22 \%$ was rated best on the basis of flavor and overall acceptability sensory parameters and was considered as the beverage base. A number of trials were conducted using different ingredient proportions. Then based on the results of sensory evaluation, the beverage formulation was standardized and the corresponding RTS was quantified. In the case of RTS prepared from fresh sugar syrup, it was observed that from 70 $\mathrm{kg}$ of fresh starfruit, $25 \mathrm{~kg}$ sugar with distilled water and ginger juice, 195 liters of RTS beverage can be prepared (Figure 3). But in the case of RTS prepared from residual sugar syrup, from $70 \mathrm{~kg}$ of fresh star fruit and osmotic fluid from osmosis of $10 \mathrm{~kg}$ of fruit, 208 liters of RTS beverage can be prepared along with $1.9 \mathrm{~kg}$ of dried slices, for which no more sugar is required (Figure 4). Lastly, it concluded the formulated objective to proliferate the use of resulting osmotic syrup in the preparation of RTS beverage followed by good acceptability and added potentials for health related issues [1, 2].

\subsection{Effect of Storage Conditions on Different Quality Characteristics of the Prepared RTS}

The quality of RTS prepared from fresh sugar syrup did not differ significantly from the one prepared using residual syrup. Hence no biochemical analysis was performed for the former juice sample. The 
quality characteristics of the RTS prepared from residual syrup were evaluated for a period of 2,4 and, 6 months as mentioned in Table 1.

Table 1. Quality characteristics of developed RTS from sesidual syrup

\begin{tabular}{|c|c|c|c|c|c|c|c|}
\hline \multirow[t]{3}{*}{ Parameters } & \multicolumn{7}{|c|}{ RTS prepared from residual syrup } \\
\hline & \multirow[t]{2}{*}{ Control } & \multicolumn{3}{|c|}{ Ambient condition } & \multicolumn{3}{|c|}{ Refrigerated condition } \\
\hline & & 2 months & 4 months & 6 months & 2 months & 4 months & 6 months \\
\hline $\begin{array}{l}\text { Total soluble } \\
\left.\text { solids ( }{ }^{\circ} \text { Brix }\right)\end{array}$ & $\begin{array}{l}15.17 \pm \\
0.05\end{array}$ & $\begin{array}{l}15.56 \pm \\
0.41\end{array}$ & $\begin{array}{l}16.50 \pm \\
0.36\end{array}$ & $\begin{array}{l}16.57 \pm \\
0.42\end{array}$ & $\begin{array}{l}15.10 \pm \\
0.1\end{array}$ & $\begin{array}{l}15.23 \pm \\
0.05\end{array}$ & $\begin{array}{l}15.37 \pm \\
0.06\end{array}$ \\
\hline $\mathrm{pH}$ & $\begin{array}{l}4.46 \pm \\
0.01\end{array}$ & $\begin{array}{l}4.41 \pm \\
0.03\end{array}$ & $\begin{array}{l}4.39 \pm \\
0.04\end{array}$ & $\begin{array}{l}3.88 \pm \\
0.05\end{array}$ & $\begin{array}{l}4.43 \pm \\
0.02\end{array}$ & $\begin{array}{l}4.36 \pm \\
0.04\end{array}$ & $\begin{array}{l}4.31 \pm \\
0.01\end{array}$ \\
\hline $\begin{array}{l}\text { Ascorbic acid } \\
(\mathrm{mg} / 100 \mathrm{ml})\end{array}$ & $\begin{array}{l}23.91 \pm \\
0.03\end{array}$ & $\begin{array}{l}22.42 \pm \\
0.04 \\
\end{array}$ & $\begin{array}{l}20.28 \pm \\
0.07\end{array}$ & $\begin{array}{l}18.41 \pm \\
0.03\end{array}$ & $\begin{array}{l}23.70 \pm \\
0.03\end{array}$ & $\begin{array}{l}22.42 \pm \\
0.01 \\
\end{array}$ & $\begin{array}{l}21.10 \pm \\
0.11 \\
\end{array}$ \\
\hline Oxalic acid & $\begin{array}{l}90.83 \pm \\
0.07\end{array}$ & $\begin{array}{l}85.84 \pm \\
0.01\end{array}$ & $\begin{array}{l}77.32 \pm \\
0.02\end{array}$ & $\begin{array}{l}63.85 \pm \\
0.01\end{array}$ & $\begin{array}{l}90.1 \pm \\
0.10\end{array}$ & $\begin{array}{l}89.17 \pm \\
0.01\end{array}$ & $\begin{array}{l}88.54 \pm \\
0.02\end{array}$ \\
\hline $\begin{array}{l}\text { Total plate } \\
\text { count }\end{array}$ & ND & ND & ND & $5 \times 10^{3}$ & ND & ND & ND \\
\hline $\begin{array}{l}\text { Total yeast and } \\
\text { mold count }\end{array}$ & ND & ND & ND & $1 \times 10^{3}$ & ND & ND & ND \\
\hline
\end{tabular}

ND denotes not detected

\subsubsection{TSS}

The initial value of TSS of the RTS beverage prepared from residual syrup was found to be $15.17 \pm$ $0.05{ }^{\circ}$ Brix which was increased to $16.57 \pm 0.42$ and to $15.37 \pm 0.06{ }^{\circ}$ Brix for ambient and refrigerated storage condition, respectively after six months of storage. The increase in TSS could be due to the enzymatic hydrolysis of polysaccharides into sugars during storage. Similar findings were reported for lime RTS and papaya-pine apple blended RTS beverages by Thamilselvi et al. [17] and Sindumathi and Premalatha [18], respectively. Two-way ANOVA (Table 2) indicated a significant variation in TSS of the refrigerated stored beverage over ambient storage irrespective of the storage period $(\mathrm{p}<0.01)$.

\section{$3.2 .2 \mathrm{pH}$}

The initial value of $\mathrm{pH}$ of the RTS beverage prepared from residual syrup was found to be $4.46 \pm 0.01$ which was decreased to $3.88 \pm 0.05$ and to $4.31 \pm 0.01$ for ambient and refrigerated storage condition, respectively after six months of storage. A slight decrease in $\mathrm{pH}$ was observed for refrigerated stored RTS compared to ambient condition. Nidhi et al. [19] and Sindumathi and Premalatha [18] were also reported similar results for bael-guava blended RTS and papaya-pine apple blended RTS beverages, respectively. Two-way ANOVA showed a significant difference between both the storage condition and storage period at an error level of 1 per cent (Table 2).

\subsubsection{Ascorbic Acid}

The initial value of ascorbic acid of the RTS beverage prepared from residual syrup was found to be $23.91 \pm 0.03 \mathrm{mg} / 100 \mathrm{~mL}$ which was decreased to $18.41 \pm 0.03$ and to $21.10 \pm 0.11 \mathrm{mg} / 100 \mathrm{~mL}$ for ambient and refrigerated storage condition, respectively after six months of storage. AA reduction could be attributed to oxidation due to oxygen present in the head space of RTS bottle. Further, the ambient storage had more detrimental impact on the decrease of AA compared to refrigerated storage. This result was in accordance with the findings of Sindumathi and Premalatha [18], Thamilselvi et al. [17], Baljeet et al. [20]. Two-way ANOVA (Table 2) indicated a significant variation in TSS of the refrigerated stored beverage over ambient storage irrespective of the storage period $(\mathrm{p}<0.01)$. An interactive $\mathrm{p}$ value of $<0.01$ indicated that the both storage condition and the storage period were also significant.

\subsubsection{Oxalic Acid}

The initial value of oxalic acid of the RTS beverage prepared from residual syrup was found to be $90.83 \pm 0.07 \mathrm{mg} / 100 \mathrm{~mL}$ which was decreased to $63.85 \pm 0.01$ and to $88.54 \pm 0.02 \mathrm{mg} / 100 \mathrm{~mL}$ for ambient and refrigerated storage condition, respectively after six months of storage. Statistical analysis of the data indicated that the oxalic acid of the RTS stored in ambient storage condition had high 
significant difference $(\mathrm{p}<0.01)$ when compared to refrigerated stored RTS (Table 2). An interactive p value of $<0.01$ indicated that the both storage conditions and the storage period were also significant.

\subsubsection{Microbial Qualities}

Initially there was no microbial load in RTS beverage after preparation and continues the same status till four months of storage. But the total plate count and total yeast and mold count increased to $5 \times 10^{3}$ and $1 \times 10^{3}$, respectively in ambient storage after six month of storage period (Table 1 ). The RTS stored in the refrigerated condition showed no microbial load even after six months of storage and was within the safe limits [21]. The negligible change in the RTS beverages might due to the anti-microbial properties of ginger juice added in the time of preparation. Similar results were also reported for Tulsi and Arugampul by Thamilselvi et al. [17] and for ginger juice by Rayaguru et al. [5].

Table 2. ANOVA Summary table for biochemical properties

\begin{tabular}{|c|c|c|c|c|c|c|c|}
\hline \multicolumn{8}{|l|}{ TSS } \\
\hline Source of Variation & SS & df & MS & $\mathrm{F}$ & \multicolumn{2}{|l|}{ P-value } & $\mathrm{F}_{\text {crit }}$ \\
\hline Storage conditions & 4.302 & 1 & 4.302 & 52.324 & \multicolumn{2}{|l|}{$1.04 \mathrm{E}-5$} & 4.747 \\
\hline Storage period & 1.391 & 2 & 0.696 & 8.459 & \multicolumn{2}{|l|}{0.00510} & 3.885 \\
\hline Interaction & 0.591 & 2 & 0.296 & 3.595 & \multicolumn{2}{|l|}{0.0598} & 3.885 \\
\hline Within & 0.987 & 12 & \multicolumn{5}{|l|}{0.082} \\
\hline Total & 7.271 & \multicolumn{6}{|l|}{17} \\
\hline \multicolumn{8}{|l|}{$\mathrm{pH}$} \\
\hline Source of Variation & SS & $\mathrm{df}$ & MS & $\mathrm{F}$ & \multicolumn{3}{|l|}{$\mathrm{P}$-value } \\
\hline Storage conditions & 0.087 & 1 & 0.087 & 74.405 & \multicolumn{3}{|l|}{$1.72 \mathrm{E}-06$} \\
\hline Storage period & 0.380 & 2 & 0.190 & 162.948 & \multicolumn{3}{|l|}{ 2.01E-09 } \\
\hline Interaction & 0.188 & 2 & 0.094 & 80.462 & \multicolumn{3}{|l|}{$1.12 \mathrm{E}-07$} \\
\hline Within & 0.014 & 12 & \multicolumn{5}{|l|}{0.001} \\
\hline Total & 0.669 & \multicolumn{6}{|l|}{17} \\
\hline \multicolumn{8}{|c|}{ Ascorbic acid (mg/100mL) } \\
\hline Source of Variation & $\mathrm{SS}$ & df & MS & $\mathrm{F}$ & \multicolumn{3}{|l|}{$\mathrm{P}$-value } \\
\hline Storage conditions & 18.707 & 1 & 18.707 & 5018.219 & $4.16 \mathrm{E}-17$ & \multicolumn{2}{|c|}{4.747} \\
\hline Storage period & 32.747 & 2 & 16.373 & 4392.256 & $6.44 \mathrm{E}-18$ & \multicolumn{2}{|c|}{3.885} \\
\hline Interaction & 1.520 & 2 & 0.760 & 203.827 & $5.46 \mathrm{E}-10$ & \multicolumn{2}{|c|}{3.885} \\
\hline Within & 0.045 & 12 & \multicolumn{5}{|l|}{0.004} \\
\hline Total & 53.018 & 17 & & & & & \\
\hline \multicolumn{8}{|c|}{ Oxalic acid (mg/100mL) } \\
\hline Source of Variation & SS & df & MS & $\mathrm{F}$ & $\mathrm{P}-\mathrm{v}$ & & $\mathrm{F}_{\text {crit }}$ \\
\hline Storage conditions & 832.184 & 1 & 832.184 & 475533.717 & 5.82 & & 4.747 \\
\hline Storage period & 421.578 & 2 & 210.789 & 120450.727 & 1.5 & & 3.885 \\
\hline Interaction & 319.894 & 2 & 159.947 & 91398.384 & 8.00 & -26 & 3.885 \\
\hline Within & 0.021 & 12 & 0.002 & & & & \\
\hline Total & 1573.677 & 17 & & & & & \\
\hline
\end{tabular}

\subsubsection{Sensory Evaluation}

Table 3 shows the composite score of the prepared RTS in terms of color, flavor, and taste. The overall acceptability was initially in the range of 8.2 to 8.5. After four months of storage, the scores of the sensory properties were found to be reduced to below 7.5 for ambient and below 8.3 for refrigerated RTS. However, the refrigerated stored sample could retain the flavor to a greater extent. This might have influenced the overall acceptability for which remarkable differences could be observed.

Storage study revealed that though there was a change in biochemical qualities of RTS samples after four and six months of storage, the changes were less remarkable in refrigerated storage as compared to those of ambient storage. This is for the obvious reason of low-temperature storage with the less degrading environment. However, these changes were not remarkable to the extent that it could be 
considered as a loss and thus the product may be inferred to be within the limits of acceptance [5]. The microbial load was well within safe limits up to four months of storage in both ambient and refrigerated condition. Sensory attributes were also above 7 in the case of ambient storage up to four months and above 8 for refrigerated stored beverage after four months which confirms an acceptable sensory score.

Table 3. Organoleptic properties of developed RTS beverage from residual syrup

\begin{tabular}{l|l|l|l|l|l|l|l}
\hline \multirow{2}{*}{ Parameters } & \multicolumn{5}{|c}{ RTS prepared from residual syrup } \\
\cline { 2 - 8 } & Control & Ambient condition & \multicolumn{3}{l}{ Refrigerated condition } \\
\hline & & $\mathbf{2}$ months & $\mathbf{4}$ months & $\mathbf{6}$ months & 2 months & $\mathbf{4}$ months & $\mathbf{6}$ months \\
\hline Colour & 8.2 & 7.9 & 7.3 & 7.2 & 8 & 8 & 8 \\
\hline Flavour & 8.4 & 8.1 & 7.7 & 7.3 & 8.4 & 8.4 & 8.2 \\
\hline Taste & 8.5 & 8 & 7.8 & 7.4 & 8.5 & 8.5 & 8.4 \\
\hline $\begin{array}{l}\text { Overall } \\
\text { acceptability }\end{array}$ & 8.37 & 8.01 & 7.61 & 7.3 & 8.31 & 8.31 & 8.2 \\
\hline
\end{tabular}

\section{Conclusion}

The average percentage fraction of usable part (sliced pieces), both end stalk and seed along with fibre were found to be $67 \%, 7 \%$ and $26 \%$, respectively in a star fruit. $70 \mathrm{~kg}$ of fresh starfruit, $25 \mathrm{~kg}$ sugar with distilled water, ginger juice gave rise to 195 liters of RTS beverage. Whereas, from $70 \mathrm{~kg}$ of fresh fruit and prepared osmotic syrup from $10 \mathrm{~kg}$ of fruit, 208 liters of RTS beverage was prepared, devoid of any extra sugar. All the biochemical qualities changed with storage period irrespective of the storage conditions. $\mathrm{pH}$, ascorbic acid and oxalic acid of RTS reduced with storage period where as an increasing trend was observed for TSS. However, the changes were maximum in ambient stored RTS beverages. The total mold count and total yeast and mold count were well within the safe limits till the end of a storage period of six months. The results suggest that addition of ginger juice not only makes the beverage nutraceutical but also increases the shelf life. This possibility may be explored further for enhancement of shelf life of suitable fruit products.

Acknowledgement. The work was supported by the Indian Council of Agricultural Research (ICAR), New Delhi.

\section{References}

1. Manda H, Vyas K, Pandya A and Singhal G, "A complete review on: Averrhoa carambola", World journal of pharmacy and pharmaceutical sciences, vol. 1, no. 1, pp. 17-33, 2012.

2. Narain, N., Bora, P. S., Holschuh, H. J. and Vasconcelos, M. D. S., "Physical and chemical composition of carambola fruit (Averrhoa carambola L.) at three stages of maturity", CYTA-Journal of Food, vol. 3, no. 3, pp. 144-148, 2001.

3. Karim AA and Wai CC, "Foam-mat drying of star fruit puree. Stability and air drying characteristics", Food Chemistry, vol. 64, no. 3, pp. 337-343, 1999.

4. Mishra DK, Study on Stone apple (Aegle marmelos correa) Candy, (M. Sc. Thesis submitted to Deptt. Of Horticulture, N.D.U.A.T., Faizabad), 2000.

5. Rayaguru K, Khan Md and Sahoo NR, "Effect of Storage on Quality of Stone Apple Ready-to Serve Beverage", Journal of Agriculture Engineering, vol. 45, no. 1, pp. 62-68, 2008.

6. Nambiar, Indian medicinal plants: a compendium of 500 species, vol. 5, Orient Blackswan, 1993.

7. Ram D, Studies on ripening, storages and processing of Stone apple (Aegle marmoelos correa) fruit, Ph.D. thesis, (N.D.U.A.T., faizabad), 1996.

8. Roy SK and Singh RN, "Studies on utilization of bael fruit for processing: I. Physicochemical characteristics of different cultivars", Indian Food Packer, vol. 32, no. 6, pp. 3-8, 1978. 
9. Saha, Anat K., and Curtis F. Brewer, "Determination of the concentrations of oligosaccharides, complex type carbohydrates, and glycoproteins using the phenol-sulfuric acid method", Carbohydrate Research, vol. 254, pp. 157-167, 1994.

10.FPO, "The Food Product Order", Central Govt. Commodities act, 1955.

11.Abdullah MZ and Mohamad-Saleh J, "Discrimination and classification of fresh-cut starfruits (Averrhoa carambola L.) using automated machine vision system", Journal of Food Engineering, vol. 76, no. 4, pp. 506-523, 2006.

12. Choudhary, M. L., "Evaluation of guava (Psidium guajava L.) varieties for processing into nectar and ready-toserve beverages (Doctoral dissertation, Indira Gandhi Krishi Vishwavidyalaya Raipur)", 2004.

13.Roy SK and Singh RN, "Studies on utilization of bael fruit for processing: II. Extraction of bael fruit pulp", Indian Food Packer, vol. 33, no. 1, pp. 5-9, 1979.

14.Ranganna, S, "Handbook of analysis and quality control for fruits and vegetable products", First edition, TataMcGraw-Hill Publishing Company Limited, New Delhi, India, 1995.

15.Archer HE, Dormer AE, Scowen EF and Watts IIWE, "Studies on the urinary excretion of oxalate by normal subjects", Clinical Science, vol. 16, pp. 405-411, 1957.

16.Rangana. S, Manual of analysis of fruit and vegetable products. Tata McGraw-Hill, 1979.

17. Thamilselvi, C., Krishnakumar, T., \& Amutha, S., "Preparation and quality evaluation of lime based herbal blended RTS beverage", Asian Journal of Dairy and Food Research, vol. 34, no. 1, pp. 54-58, 2015.

18.Sindumathi. G and Premalatha. M. R, "Development and Storage Studies of Naturally Flavored PapayaPineapple Blended Ready-to-Serve (RTS) Beverages," International Journal of Science and Research, vol. 4, no. 2, pp. 856-860, 2015.

19.Nidhi, Gehlot, R., Singh, R., \& Rana, M. K., "Changes in chemical composition of ready-to-serve bael-guava blended beverage during storage," Journal of food science and technology-mysore, vol. 45, no. 4, pp. 378-380, 2008.

20.Baljeet, S. Y., B. Y. Ritika, and R. Sarita, "Studies on development and storage of whey-based pineapple (Ananas comosus) and bottle gourd (Lagenaria siceraria) mixed herbal beverage," International Food Research Journal, vol. 20, no. 2, pp. 607-612, 2013.

21.International Commission on Microbiological Specifications for Foods. Microbial Ecology of Food Commodities. Blackie Academic \& Professional, vol. 6, 1998. 